\title{
How the EU came to open accession negotiations with Turkey: The role of the "well-placed Brits"
}

\author{
Natalie MARTIN
}

The current state of the Turkey-EU accession process is parlous as Turkey appears to be moving away from meeting the Copenhagen criteria rather than towards them. In fact accession negotiations deteriorated almost as soon as they began, in October 2005. ${ }^{1}$ This paper argues that in order to understand the complex cause and effect of the subsequent cycle of decline in EU-Turkey relations it is first necessary to examine why the EU agreed to open accession negotiations at all.

Hence the research question addressed here is why the EU agreed to open accession negotiations with Turkey when there was considerable opposition to the idea for normative and cultural reasons. Indeed, as Frank Schimmelfennig has outlined, the European Council's December 2004 decision to open negotiations with Ankara was "one of the most controversial decisions ever taken" by the EU. ${ }^{2}$ The aim of this paper is to show how this happened. It argues that the Turkish case for accession negotiations to be opened was artificially expedited in the period up to December 2004 by the skilful diplomacy of Turkey's advocates within the EU amidst a geostrategic constellation favourable to the Turkish case. The upshot of a series of events dating back to 1999 was that those member states who were less keen on the Turkish case felt rhetorically entrapped into agreeing to open accession negotiations in October 2005.

It draws on Schimmelfennig's Normative Institutionalist approach to argue that in December 2004 the member states' room for manoeuvre on the Turkish case for accession had been restricted by their previous insistence on the Copenhagen criteria. ${ }^{3}$ Having stressed this significance repeatedly to Turkey their ability to then oppose the Turkish case was thwarted when Ankara unexpectedly made considerable constitutional reform between 2002 and 2004. Moreover using Schimmelfennig's theoretical framework it is argued that this was a deliberate strategy by Turkey's advocates. In other words they believed Turkish accession was in the wider security interest of the EU and had calculated that the only way Turkey could move forward to accession was to make progress towards meeting the Copenhagen criteria. Therefore

1. W. HALE, Human Rights and Turkey's EU Accession Process: Internal and External Dynamics, 2005-10, in: South European Society and Politics, 2(2011), pp.323-333.

2. F.SCHIMMELFENNIG, Entrapped again: The way to EU membership negotiations with Turkey, in: International Politics, 4(2009), p.413. See also N. NUGENT, The EU's response to Turkey's membership application: Not just a weighing of costs and benefits, in: Journal of European Integration, 4(2007), pp.481-502.

3. See F. SCHIMMELFENNIG, Entrapped again ..., op.cit.; D. THOMAS, Explaining the negotiation of EU foreign policy: Normative Institutionalism and alternative approaches, in: International Politics, 4(2009), pp.339-357. 
they tried to enable the new AKP government to maximise the impact of its reforms with the intention of obliging the EU to honour its previous commitments.

In so doing it adds theoretically and empirically to the existing literature. Theoretically this paper argues that rhetorical entrapment can be active as well as passive. Empirically it highlights the significant role of Turkey's advocates in this process between 2002 and 2004. These advocates were primarily based in the UK Foreign and Commonwealth Office (FCO) but were helped by the similarly motivated Enlargement Commissioner Günter Verheugen and some "well placed Brits" within his DG Enlargement. ${ }^{4}$

In this way it argues that Turkey's progress 2002-2004 was artificially expedited by geostrategically motivated actors but was unsustainable thereafter. This constitutes an explanation of why and how Turkey has come to be in accession negotiations and contributes to an explanation of why the accession process hit the buffers soon after and has remained in stalemate since.

\section{Metatheoretical framework}

In short, this paper argues that the UK, primarily although not exclusively, was acting strategically within the normative EU environment when it used the EU's own norms instrumentally to further the Turkish case. Such a complex argument therefore requires a metatheory which goes beyond the either/or positivist/post-positivist debate.

Scientific, or Critical Realism has been classified as the fifth debate in International Relations and provides a metatheoretical justification for this eclectic approach. ${ }^{5}$ For Critical Realists material and ideational factors are equally valid and any decision about the relative influence of them should be made on the basis of the evidence available and judged on the quality of that evidence. Critical Realism is post-positivist in the sense that it is a critique of the dominance of Positivism but it is not post-positivist in the sense that it rejects rationalist approaches per se. For Jonathan Joseph and Colin Wight both Positivism and post-Positivism "commit two closely related errors" in that they presume the other is wrong.

4. The "well-placed Brits" was a phrase used repeatedly by this interviewee who was a senior member of the UK Permanent Representation in Brussels. Interview 16.

5. 'Scientific Realism' has been used by Alexander Wendt as an epistemology to justify his Social Constructivist 'via media' approach to International Relations. However Wight tends to use the term 'Critical Realism' as the application of Scientific Realism to social science in order to distance his approach from that of Wendt. See A. WENDT, Social theory of international politics, Cambridge University Press, Cambridge, 1999; C. WIGHT, Agents, structures and International Relations: Politics as ontology, Cambridge University Press, Cambridge, 2006; J. JOSEPH, C. WIGHT (eds), Scientific Realism and International Relations, Palgrave Macmillan, Basingstoke, 2010; M. KURKI, C. WIGHT, International Relations and social science, in T. DUNNE, M. KURKI, S. SMITH (eds), International Relations Theories: Discipline and Diversity, Oxford University Press, Oxford, 2010, pp.14-35. 
The tendency to do so arose from the previous dominance of Positivism and the backlash it provoked in the 1980s. ${ }^{6}$ Critical Realism argues instead that "science" is a "pragmatic product in process" and we should judge what Roy Bhaskar calls "transitive" knowledge by its rigor. ${ }^{7}$ The utility in this case is access to complex explanation and understanding. I argue that the questions surrounding the EU-Turkey accession process cannot be answered with recourse to either material or ideational factors as there is a complex interplay between them. Instead my intention is to make a case, on the balance of probabilities, for a given explanation.

This approach could be seen as a return to "area studies" rather than "political science" with the epistemological conflict associated with that debate. ${ }^{8}$ Alternatively it can be seen as an example of the "genre blurring" advocated for political "science" by Mark Bevir and Roderick A.W. Rhodes or the strategic-relational model of Robert Jessop as applied to International Relations and foreign policy analysis by Timothy Lim and Elisabetta Brighi. ${ }^{9}$ What these approaches have in common is the move away from parsimony as a virtue in favour of the use of "thick description" or historical method in the interest of context. As Lawson argues, the division between social science and history is artificial and there is no need for an "eternal divide" between them. Instead Lawson argues that history can be "scientific" in approach as long as "science" is not defined by Positivists. "History is social science. It is an approach that emplots, narrates and analyses causal stories". ${ }^{10} \mathrm{He}$ argues instead for "analytical narratives which accept that temporality is social, events are theorisable and narrativity is an indispensable part to causal stories". ${ }^{11}$

6. J. JOSEPH, C. WIGHT (eds), Scientific Realism ..., op.cit., p.25. See also J. FEARON, A. WENDT, Rationalism v. Constructivism: A sceptical view, in: W. CARLSNAES, T. RISSE, B. SIMMONS (eds), Handbook of International Relations, Sage, London, 2002, p.55.

7. R. BHASKAR, Realist theory of science, Alma, York, 1975. See also C. WIGHT, Agents, structures and International Relations ..., op.cit., p.61.

8. See G. KING, R. KEOHANE, S. VERBA, Designing social inquiry: Scientific inference in qualitative research, Princeton University Press, London, 1984; R.H.BATES, Area studies and the discipline: A useful controversy?, in: PS: Political Science and Politics, 2(1997), pp.166-169 and M.TESSLER, J. NACHTWEY, A. BANDA, Introduction: The area studies controversy, in P. O'MEARA, H. MEHLINGER, R. NEWMAN (eds), Changing perspectives on international education, Indiana University Press, Bloomington, 2001, pp.67-76.

9. C.GEERTZ, Local knowledge: Further essays in interpretive anthropology, Basic Books, New York, 1983; M. BEVIR, R.A.W. RHODES, Studying British government: Reconstructing the research agenda, in: The British Journal of Politics and International Relations, 2(1999), pp.215-239; R. JESSOP, Critical Realism and the strategic-relational approach, in: New Formations, 56(2005), pp.40-53; R.A.W.RHODES, From Prime Ministerial leadership to court politics: Broadening horizons by blurring genres, in: P. STRANGIO, P. 'T HART, J. WALTER (eds), Prime Ministerial Leadership: Power, Party and Performance in Westminster Systems, Oxford University Press, Oxford, 2012; T. LIM, Doing comparative politics: An introduction to approaches and issues, Lynne Reiner, Boulder Colorado, 2006; E. BRIGHI, Foreign policy and the international/domestic nexus, Routledge, London, 2013.

10. G. LAWSON The eternal divide? History and International Relations, in: European Journal of International Relations, 2(2012), pp.203-226.

11. P.T. JACKSON, The conduct of inquiry in International Relations: Philosophy of science and its implications for the study of world politics, Routledge, London, 2010. 
The methodology employed here is qualitative and relies on media and official documentary sources and approximately 40 semi-structured interviews with elite players within Turkey, the EU member states and the EU carried out between 2009 and 2013.12 I have taken a process-tracing approach to establish the causal mechanisms involved. ${ }^{13}$

\section{Background}

Turkey was one of the first ever applicants to aspire to join, what was then, the EEC. Its 1959 application pre-dates the UK's. An Association Agreement was signed in 1963 but progress was slow thereafter primarily because of Turkey's poor record of liberal democracy and human rights. ${ }^{14}$ Ankara's formal application in 1987 was rejected in 1989 on economic and normative grounds and the Luxembourg European Council presidency conclusions, of December 1997, reiterated these normative concerns as justification for failing to include it in the Agenda 2000 eastern enlargement round. ${ }^{15}$ By this time Ankara was lagging behind previously comparable states such as Spain, Portugal and Greece, the first wave of the central and eastern European countries (CEECs) and the highly politically sensitive Republic of Cyprus.

However, Turkey's fortunes changed in 1999 when Ankara was offered candidacy by the Helsinki European Council. This symbolic breakthrough encouraged its domestic pro-EU lobbies such as the Turkish Industry and Business Association (Türk Sanayicileri ve İşadamları Derneği, TUSIAD) to lobby for the reforms necessary to progress. Constitutional progress remained slow after 1999 but, by the Copenhagen European Council in December 2002, the reform process had started. ${ }^{16}$

The election of the Adelet ve Kalkinma Partisi (Justice and Development Party, AKP) in November 2002 with a strong parliamentary majority was a significant break with the previous patterns of coalition party politics in Turkey. Prior to its election, the UK Ambassador to Turkey, Sir Peter Westmacott, had ascertained the AKP's

12. By "elite players" I mean key actors in member state governments in the civil service and political parties as well as senior members of the EU institutions. This term indicates the prevalence of those who had taken and influenced the decisions rather than just implemented them. The interviews were all carried out under Chatham House rules.

13. See A. GEORGE, A. BENNETT, Case studies and theory development in the social sciences, MIT Press, Massachusetts, 2005; J. CHECKEL, It's the process stupid! Process tracing in the study of European and international politics, Arena Paper $n^{\circ} 26$, Oslo, 2005); T. RUBACK, Let me tell the story straight on: Middlemarch, process-tracing methods and the politics of narrative, in: British Journal of Politics and International Relations, 4(2010), pp.477-497.

14. G.S. HARRIS, Military Coups and Turkish Democracy, 1960-1980, in: Turkish Studies, 2(2011), pp.203-213.

15. Although this was followed by the conciliatory Matutes package and the Customs Union in 1995. B.YILMAZ, The relations of Turkey with the European Union: Candidate forever?, Center for European Studies, Working paper $n^{\circ}$ 167, Harvard University, Harvard, 2008.

16. Interview 26. See also New era opens with EU reforms, in: Turkish Daily News, 04.08.2002. 
willingness and ability to implement the constitutional reform necessary to make EU accession progress. ${ }^{17}$ This enabled the UK Prime Minister, Tony Blair, to lobby hard at the Copenhagen European Council in December 2002 for a diplomatic wordage in the presidency conclusions that would mollify Turkey's critics but keep Ankara "on side" and maintain the reform process under the AKP with a view to achieving the opening of accession negotiations. ${ }^{18}$ The Copenhagen presidency conclusions pledged to reconsider Ankara's case two years hence on the basis of a recommendation from the European Commission. Tony Blair, with the help of Peter Westmacott, was then also able to convince Recep Tayyip Erdogan and Abdullah Gul that this compromise, far from being a snub to Turkey, was an opportunity for advancement to Brussels.

\section{Ticking the boxes}

The UK's geostrategic motivation at this time was both long term (that the UK, as well as the USA, NATO and the EU, would benefit from a Europeanized Turkey) and short term. It was hoped bringing Turkey further into the EU fold would facilitate a solution to the Cyprus issue before the island joined the EU in 2004 and smooth the difficulties of ESDP forces accessing NATO facilities which had been blocked by Turkey since $1999 .{ }^{19}$

The UK's acknowledgement of Turkey's geostrategic value was not a new phenomenon. In the late 1940s Britain had been "determined to favour the Turkish case" after the UK's withdrawal from Palestine as both Harold Macmillan and Anthony Eden thought it "constituted Britain's firmest ally in the region" to maintain the UK's interests. ${ }^{20}$ In the 1950s this view was strengthened by the evolution of NATO and the role Turkey played within it. ${ }^{21}$ The NATO perspective on UK-Turkish relations endured through the Cold War and remained strong in the 1980s and into the 1990 s. $^{22}$

17. Interviews 15,19 and 23

18. Interview 19.

19. Interviews 15 and 9. See also A. MISSIROLI, EU-NATO cooperation in crisis management: No Turkish delight for ESDP, in: Security Dialogue, 1(2002), pp.9-26; A. MISSIROLI, Turkish delights? A response to Bilgin, in: Security Dialogue, 3(2003), pp.351-355; P.BILGIN, The peculiarity of Turkey's position in EU/NATO military/security cooperation: A rejoinder to Missiroli, in: Security Dialogue, 3(2003), pp.345-349; S. SAYARI, Challenges of Triangular Relations: The US, the EU, and Turkish Accession, South European Society and Politics, 2(2011), pp.251-263.

20. R. ALDRICH, M.HOPKINS (eds), British intelligence, defence and diplomacy since 1945: British policy in the post-war world, Frank Cass, Ilford, 1994, p.5.

21. E. HATZIVASSILLIOU, The Cyprus question and the Anglo-American special relationship, in: R. ALDRICH, M.HOPKINS (eds), British intelligence ..., op.cit., p.149.

22. Interviews 11, 18 and 23. Indeed it is still a current strategy. As recently as 2011 the Foreign Secretary William Hague described the UK Turkey relationship as entering a 'golden age', Britain and Turkey: A new special relationship, in: Daily Telegraph, 22.11.2011. 
The "opportunity" provided by the 2002 Copenhagen European Council presidency conclusions was to explicitly link Turkish accession progress with its meeting of the Copenhagen criteria and place the European Commission in the role of arbiter. The logic was that, if Turkey made constitutional progress, and, if the Commission published a favourable progress report in the autumn of 2004, then the member states would find it hard to backtrack on these commitments. For the FCO this was a repeat of the strategy employed in the CEEC enlargement round. ${ }^{23}$ The intention was to "get the Turks into a place where they could tick off all the points for joining". This was "such an obvious thing to do" because if Turkey's problematic record of democracy and human rights could be addressed the reasons left to object would be "cultural" and even staunch opponents such as Austria and Cyprus would be reluctant to openly express reasons based solely in cultural prejudice in an EU forum. ${ }^{24}$

"You use the logic of the process and you are not prepared to say that Turkey is fundamentally different [...] if they have passed the post then you have got to let them move to the next stage and that is how we squeezed them through". ${ }^{25}$

The UK Ambassador to Turkey, Sir Peter Westmacott, was pivotal in this exercise. He was a "brilliant diplomatist", and, as already outlined, had done a "sterling job" of assessing the AKP's intentions and capability in 2002. ${ }^{26}$

"We knew a lot about them before they took power... and it convinced us the AKP was going to be an effective proponent of Turkey's inclusion because they had come to the conclusion that the best way to counter the military and the deep state was to join the EU". 27

The AKP were in favour of closer ties to the EU because of the perceived religious freedom it would bring with it particularly over the headscarf issue. However, Westmacott's assessment of the AKP was that whilst it was not secular in the Kemalist sense, neither was it Islamist in a fundamentalist sense. AKP politicians Abdullah Gul and Yasar Yakis in particular were "known in previous incarnations" and were able to "fill a political vacuum". This encouraged the UK FCO to push the Turkish case forward. ${ }^{28}$

23. Interview 20. See also F. SCHIMMELFENNIG, The community trap: Liberal norms, rhetorical action and the eastern enlargement of the EU, in: International Organisation, 1(2001), pp.47-80; U. SEDELMEIER, Constructing the path to eastern enlargement: The uneven policy impact of EU identity, Manchester University Press, Manchester, 2005; N. FONT, Why the EU gave Turkey the green light, in: Journal of Contemporary European Studies, 2(2006), pp.197-212 and M. VACHUDOVA, Historical Institutionalism and the EU's eastern enlargement, in: S.MEUNIER, K. MCNAMARA (eds), Making history: European integration and institutional change at fifty, Oxford University Press, Oxford, 2007, pp.106-114.

24. Interviews 11,16 and 17.

25. Interview 16.

26. Interviews 13 and 23 .

27. Interview 15 .

28. Interviews 19 and 25 . 
"We [the UK] pursued it and it is true to say that if it had not been for British sponsorship [read: advocacy], we would not have started accession negotiations with Turkey. We can take a lot of the credit". 29

Sir Peter Westmacott had "extremely good access" to the upper echelons of the AKP and became an unofficial advisor "on call" to the government. His role was to "liaise" with the AKP and "engage with them to get the negotiations started". He had won the trust of the Foreign Minister Abdullah Gul and the Prime Minister Recep Tayyip Erdogan and they saw "someone working in our interests and we appreciated his performance". "It was him [Westmacott] who guided [...]; his performance was outstanding. It was not a government duty but as if it was something in which he genuinely believed". 30

Westmacott "was the EU expert for the AKP" and was able to advise the AKP on which policies would meet normative concerns, and thereby hasten accession, such as judicial reform, Kurdish freedom of speech, human rights in general and women's rights in particular. ${ }^{31} \mathrm{He}$ was also able to advise the AKP on how to "sell" these changes to its socially conservative constituency. His diplomatic skills meant he was able to be "very tough on telling them what they should do". He had the "gift of delivering the tough message without losing the way". "He was restrained enough not to give the impression that he was advising but whoever was listening to Westmacott would understand that what he was saying was making sense". 32

\section{"All the tools in the enlargement trick box"}

The UK FCO was helped in this regard by the Enlargement Commissioner, Günter Verheugen, a former member of the Gerhard Schroeder government, and several "well-placed Brits" within the Commission who shared the FCO's geostrategic motivation on Turkey and had also sensed an opportunity to move the Turkish case forward after the Copenhagen European Council in December 2002. ${ }^{33}$ The Enlargement Commissioner, Verheugen, felt the geostrategic case for Turkish accession was strong because of the incentive it provided to improve human rights and democracy. For this reason he favoured a pragmatic approach such as that accorded to Bulgaria and Romania. He felt Turkey should be judged by its intention to reform as well as its achievements to date. ${ }^{34}$

29. Interview 16 .

30. Interviews 19 and 25 .

31. Interview 23. According to this source the AKP once complained when PW was on annual leave that he was not available to answer a query.

32. Interviews 16,23 and 25 .

33. Interviews $2 \mathrm{a}$ and 16 .

34. Interview 4. 
However, DG Enlargement was also aware that Turkey would need a solid record of improvement to have any chance of persuading the other Commissioners and the member state governments to back the policy. In spite of the geostrategic arguments in Turkey's favour it was still inconceivable within the EU for Turkey to advance without meeting the Copenhagen criteria. In early 2003 Verheugen, sent his "best people" to the EU representation in Ankara to "guide" the AKP through the reform process. A strong reform track record would enable the pragmatic approach to Turkey, which was preferable for geostrategic reasons, to be made. ${ }^{35}$ It

"would ultimately enable Günter Verheugen to make the case in 2004 that Turkey was able to meet the criteria. Verheugen knew exactly what he wanted. We [the European Commission] needed to build up a track record". ${ }^{36}$

Accordingly, Verheugen spent a lot of time in 2003 and 2004 building personal relationships with the Turkish Foreign Minister, Abdullah Gul, and the Prime Minister, Recep Tayyip Erdogan, whose initial bond with the Commissioner was built upon their common love of football and knowledge of the German Bundesliga. Verheugen made it clear to Erdogan and Gul that he needed to see evidence of non-negotiable "concrete deliverables" such as measures to outlaw torture and to improve the rights of the Kurdish minority. There was an "explanation of visions that if certain things were done it would allow such and such to happen" and pressure was put on the Turkish government to continue with the reform process. The Commission's strategy was very similar to that of the UK FCO. There was a "concerted effort to use all the tools in the enlargement trick box". 37

\section{A sense of obligation: Pacta sunt servanda and the Cyprus issue}

From 2002 to 2004 the UK FCO and the European Commission's DG Enlargement were both working to further the Turkish case. They used EU norms, as espoused by the "EU theologians" (EU officials dedicated to the normative liberal democratic values of the EU; most of them "tended to be French"), ${ }^{38}$ strategically and there was overlap thanks to some "well-placed Brits" within the Commission. The judgement was that there would be a strong sense of obligation to Ankara if Turkey could be shown to have made significant progress acknowledged by the European Commission in a progress report. It "was a matter of obligation for the EU to agree to open accession negotiations with Turkey. You cannot not do something". ${ }^{39}$ In other words:

\footnotetext{
35. Interviews $2 \mathrm{~b}$ and 4 .

36. Interview 3.

37. Interviews $2 \mathrm{a}, 3$ and 4.

38. Interview 21 .

39. Interview 9.
} 
"You cannot tell somebody, OK, you are ready for negotiations and then never open them. Sometimes the pressure of the policies that the EU has set for itself is such that we have to start". ${ }^{40}$

This view was also prevalent in wider EU civil society such as the report for the Open Society Foundation by Martti Ahtisaari, and others, in September 2004 which warned that the EU's integrity was at stake if the EU failed to acknowledge the progress made by Turkey since 2002 .

"Further delay would damage the European Union's credibility and be seen as a breach of the generally recognized principle that 'pacta sunt servanda' (agreements must be kept)". ${ }^{41}$

Another factor which inclined the EU to think favourably of the Turkish case was the outcome of the Annan Plan referendum in April 2004 on the reunification of Cyprus. ${ }^{42}$ The Greek Cypriots voted $75.8 \%$ against whilst the Turkish Cypriots were $65 \%$ in favour. The Turkish government felt "short changed" and "very resentful with some justification" because of the political risks it had taken in advocating the policy. This was also the "worst situation that could be imagined" for the EU as it left it in the difficult position of being about to admit a divided, and disobliging, Cyprus whilst alienating Ankara. This uncomfortable situation heightened a "sense of obligation" within the European Commission, and the member states, to Turkey in respect of the recommendation to be given in the 2004 Progress Report. ${ }^{43}$ The AKP government had fulfilled its part of the Cyprus Annan Plan deal at some political risk and deserved to be rewarded. Alternatively geostrategically the EU could not risk the alienation which was likely to follow if the AKP did not get some kind of quid pro quo over Cyprus.

There were other aspects to this geostrategic case: By 2004 the imperative to find solutions on ESDP and eastern enlargement which had been dominant at Copenhagen in 2002 had waned. ESDP had come to terms with its role and eastern enlargement was virtually a done deal with or without Cypriot reunification. However, the events of September 11th 2001 had reiterated Turkey's geostrategic value as a Muslim democracy to many member states as had its sceptical stance to the Iraq War in 2003. In addition, as the EU had inherited the Cyprus issue by agreeing to admit a divided island it was anxious to keep Greek-Turkish relations cordial. Hence, not only was

40. Interview 7.

41. M. AHTISAARI, Turkey in Europe: More than a promise? Report of the Independent Commission on Turkey, Open Society Foundations, New York, 2004, p.42.

42. For background on the Cyprus issue see T. DIEZ, The European Union and the Cyprus conflict, Manchester University Press, Manchester, 2002; C. DODD, The Cyprus imbroglio, Eothen, Cambridge, 1998; D. HANNAY, Cyprus: The search for a solution, I.B.Tauris, London, 2005; J. KERLINDSAY, From U Thant to Kofi Annan: UN peacemaking in Cyprus, 1964-2004, Occasional Paper 5/05, St Antony's College, Oxford, 2005; M. MUFTULER-BAC, A.GUNEY, The European Union and the Cyprus problem 1961-2003, in: Middle Eastern Studies, 2(2005), pp.281-293 and C.MELAKOPIDES, Unfair play: Cyprus, Turkey, Greece, the UK and the EU, Martello Paper $\mathrm{n}^{\circ}$ 29, Queen's University, Kingston, Canada, 2006.

43. Interviews 4 and 19. 
there a sense of moral obligation to the AKP government there was also a sense that the price for Ankara's continuing cooperation over Cyprus was the opening of accession negotiations.

"It was part of the deal. The Turks would not make too much of a problem in Cyprus and the EU at its turn would give Turkey accession negotiations. [...] it was all bound up with Cyprus". ${ }^{44}$

This sense of obligation and continuing geostrategic value vindicated the UK FCO's (and Günter Verheugen's) judgment two years previously. It was in the EU's long term interest to placate and manage Turkey but this would have been much more difficult - if not impossible thanks to the "theologians" - if reforms had not been made. The Turkish case for accession was galvanized by the constitutional modification which had already taken place with the promise of more to come. ${ }^{45}$

\section{Sufficiently fulfils...}

The 2004 Progress Report on Turkey was published on October $6^{\text {th }} 2004$ (European Commission 2004) pronouncing that

"in view of the overall progress of reforms [...] the Commission considers that Turkey sufficiently fulfils [my italics] the political criteria and recommends that accession negotiations be opened". 46

The "sufficiently fulfils" wording was a "creative formula" which had allowed the European Commission to concede the obvious point that Turkey had not yet fully met the Copenhagen criteria whilst not totally compromising Brussels' normative principles.

"Fundamentally at that time we considered that the political criteria were sufficiently met. There were some areas of concern but overall the legal framework was in place". ${ }^{47}$

44. Interview 38 .

45. Also, during a visit to Diyarbakir in eastern Turkey in September 2004, in advance of the Progress Report, he was impressed by hearing a children's choir singing songs in a Kurdish language - which until very recently had been outlawed. This "showed Verheugen that something was changing on the ground so he could justify a pragmatic approach to the Copenhagen criteria". Interviews 3 and 4.

46. Communication from the Commission to the Council and the European Parliament - Recommendation of the European Commission on Turkey's progress towards accession. COM/2004/0656 final, available at: http://eur-lex.europa.eu/legal-content/EN/TXT/?uri=CELEX:52004DC0656.

47. Interview 2a. See also Interviews 1 and 3. 
However, the progress report also contained caveats. Turkey was warned that reform must continue or negotiations could be suspended and that the accession negotiations were an "open-ended process whose outcome cannot be guaranteed beforehand". 48

In order to get this far the Progress Report had had to navigate obstacles within the European Commission and the Council. Within the European Commission, only the Austrian Commissioner Franz Fischler and his Dutch counterpart Fritz Bolkestein spoke publically against the Turkish case. They used "emotional" arguments that Turkey was too populous, not European and not Christian which Verheugen found "easy to counter". 49

Verheugen's case in favour of opening accession negotiations with Turkey was two-fold. He stressed the well-versed geostrategic risks of alienating Ankara in terms of its cooperation with ESDP missions, the ongoing Cyprus talks and Turkey's wider symbolic value as a Muslim democracy. "He said that if the promise was not kept it would be terrible [...] not only for Turkey but it would be a signal for the whole Muslim world". ${ }^{50}$ However, Verheugen also stressed the concomitant benefits to the EU of a Europeanized Turkey as a result of the conditionality of the Copenhagen criteria. To support the latter he highlighted the strong positive influence the prospect of negotiations had already had on the AKP. Whilst it was clear that legitimate concerns on human rights remained, Verheugen cited the unprecedented progress already made and the potential for more. ${ }^{51}$ By alienating Turkey at such a vital stage Verheugen argued the EU would lose its potential to restrain the excesses of the AKP such as it had done over the issue of criminalizing adultery in September 2004. ${ }^{52} \mathrm{He}$ also emphasized the need to maintain Turkish cooperation with issues such as energy pipelines and Justice and Home Affairs (primarily people and drug trafficking). ${ }^{53}$

Verheugen's political skills were crucial in gaining agreement to the wording of the progress report. He was an arch "political animal" who "invested in relationships" with the major players within the EU and Ankara both for and against the proposal.

48. Communication from the Commission to the Council and the European Parliament - Recommendation of the European Commission on Turkey's progress towards accession. The 'open-ended' clause was the price paid to Franz Fischler which would allow his Prime Minister, Wolfgang Schüssel, to interpret the recommendation as a form of 'privileged partnership' rather than the opening of full accession negotiations and appease his public opinion. Interview 4.

49. Interview 4.

50. Ibid.

51. HUMAN RIGHTS WATCH, Turkey: EU bid hinges on further rights reforms, 15.06.2004 and Advisory Note to Journalists Covering the Release of Regular Report on Turkey and Recommendations, 04.10.2004.

52. Agence France Press, Plans by EU aspirant Turkey to recriminalize adultery split, 07.09.2004.

53. See G. WINROW, Turkey and the east-west gas transportation corridor, in: Turkish Studies, 2(2004), pp.23-42; G. WINROW, Problems and prospects for the fourth corridor: The position and role of Turkey in gas transit to Europe, Oxford Institute for Energy Studies, Paper NG30, 2009; P. ROBINS, From small time smuggling to big time racketeering: Turkey and the Middle East, in: M. BERDAL, M. SERRANO (eds), Transnational Organized Crime and International Security, Lynne Reiner, Boulder, 2002, pp.141-152. 
"That was the key [building relationships] to getting a recommendation [to open accession negotiations]. Without that I can barely envisage a scenario in which a positive recommendation could have occurred if it had not been for [Verheugen]".

Whilst Verheugen worked to persuade reluctant fellow Commissioners, the Commission also worked in "very very very close" consultation with the "big three" member states of the UK, France and Germany on the wording to ensure it would not fail to advance at the Brussels European Council. It was "tailored to make sure that we got the answer that the question was looking for".

"Every single word of the progress report was agreed with Berlin, Paris and London [...], every [...] single [...] word and particularly [with] Paris. Some parts, words and phrases, were agreed with Chirac directly. It was carefully prepared. We invested hours [...]. There were no surprises". 54

\section{Cultural opposition remains}

Nevertheless, in spite of the favourable progress report, several hurdles remained for those member states in favour of Turkish accession. Some member state leaders in favour of Turkish accession were dealing with public opinions and rival politicians who remained opposed. French public opinion was around $20 \%$ in favour leaving Jacques Chirac's support for Turkey "out of line" with public opinion and that of his Union pour un Mouvement Populaire (UMP) including his political rival Nicolas Sarkozy. 55

Chirac had already made concessions by announcing that he would seek to amend the French constitution such that the admission of any new member to the EU should be subject to a referendum (although this would not apply to Romania, Bulgaria or Croatia). Gerhard Schroeder faced minor and uneasy normative resistance within the SPD party and stronger opposition from his CDU (Christian Democrat Union) rival Angela Merkel who advocated "privileged partnership" for Turkey rather than full accession. ${ }^{56}$

As a result, Chirac suggested that a form of "special partnership" for Turkey may be preferable.

54. Interview 3.

55. BBC News Online, EU views on Turkish bid, 30.09.2005; Chirac promises Turkey referendum, in: Financial Times, 02.10.2004. See also K. BARYSCH, What Europeans think about Turkey and why?, Centre for European Reform, London, 2007.

56. Agence France Press, Chirac proposes constitutional change for referendum on Turkish EU entry, 01.10. 2004; Chirac's gamble, in: Financial Times, 05.10.2004. Deutsche Press Agentur, Germany split on Turkish EU membership, 03.10.2004. 
"It is not impossible that the road taken by Turkey does not allow it to adhere to all of the values of Europe. In that case, we must find the means to create sufficiently strong links [...] without there being full integration". 57

In an article in the Financial Times later in November 2004 the former French President, Valéry Giscard d'Estaing, a long-time critic of Turkish accession, also warned of the dangers of extending the EU too much and too far and urged against offering full membership to Turkey.

"What is most surprising is the way most European leaders have let themselves be drawn into a simplistic choice between agreeing to negotiations on Turkey's accession to the EU and closing the door in its face". 58

This was in keeping with the general timbre of the opposition to the Turkish case. In September 2004, Fritz Bolkestein had remarked that Turkish accession would mean the "liberation of Vienna (from the Turks) in 1683 would have been in vain". The Vatican was also vocal against the Turkish case and the European Parliament's centre right grouping, the European People's Party (EPP), gave the job of coordinating its position amongst EU governments to the Austrian Prime Minister, Wolfgang Schüssel who was known to have reservations about the Turkish case and to be a supporter of the Angela Merkel "privileged partnership" approach. ${ }^{59}$ The puzzle remains therefore why the actions of the member states at the Brussels European Council in December 2004 did not reflect this opposition.

\section{The geostrategic use of norms}

The answer is that, by this time, the combination of geostrategic value, and the reform progress which had made the Commission's favourable progress report possible, had neutralized the opposition of those member states opposed to Turkey on normative grounds. The geostrategic case in favour was compelling and they could see that further reform was possible. As a result the notion of opening accession negotiations with Turkey became "an idea that at any other point in time would not have been possible". 60

So, as the 2004 Brussels European Council approached, the member states were being asked to judge the Turkish case on the basis of a progress report which was largely favourable (and contained crucial appeasing caveats) in the context of strong

57. Associated Press, Chirac evokes another Turkey scenario: close ties, not membership, 05.11.2004.

58. A better European bridge to Turkey, in: Financial Times, 25.11.2004.

59. Turkey's legacy casts long shadow over talks with EU; Islamisation warning clouds Turks' EU drive; France calls for fall back option in Turkish EU negotiations, all in: Financial Times, 06.09.2004, 08.10.2004 and 09.11.2004. See also B.SAATCIOGLU, Turkey-EU Relations from the 1960s to 2012: A Critical Overview, in: B. AKCAY, B. Yilmaz (eds), Turkey's Accession to the European Union: Political and Economic Challenges, Lexington Press, Plymouth, 2012, p.14.

60. Interview 39. 
geostrategic reasoning. This rhetorically entrapped those member states which had been normatively opposed to the Turkish case primarily because they could see the argument that it was in the EU's interest to encourage further reform in Turkey. Their normative reasons to oppose Turkey had been weakened and they remained reluctant to publically voice the more illiberal "cultural" reasons. There was a perception that they had been "wrong footed" and there was "no way out" of offering to open accession talks with Turkey because Ankara had made significant constitutional reform. 61

Turkey's normative opponents were trapped within the norms of social interaction the European Union which was premised on adherence to principles of "politeness", fair play and liberal values. It would be "quite a big thing to be sitting in the Council of Ministers wanting to stop such and such [...]. Countries would need to look around for support". To keep pushing normative "concerns" in the face of unprecedented progress in Turkey may have appeared to be the result of prejudice and this was something states were keen to avoid in open EU fora. They "would not want to be seen as anti-Muslim or some kind of racist reason". 62

However, more significantly, it also actively rhetorically entrapped those countries whose opposition to Turkey was more "cultural" than normative. In addition, the number of active cultural opponents at the Brussels European Council had dwindled due to the pressing geostrategic considerations and comprised primarily of Austria and Cyprus. ${ }^{63}$ Moreover, Austria's residual "cultural" objections had been appeased with the "open ended" wording of the progress report and a deal for Croatia to become an EU candidate. ${ }^{64}$ Ultimately, it was only Cyprus which remained a problem. As noted by an unnamed EU diplomat, "the Greek Cypriots wanted to rub the Turks' noses in it". 65

61. Interview $2 \mathrm{a}$

62. Interview 11.

63. At this time Greece was in favour of Turkish accession. See Agence France Press, Greek PM in Cyprus for key talk on Turkish EU bid, 12.11.2004. See also F.S. LARRABEE, Greek-Turkish relations in an era of regional and global chang, in: Southeast European and Black Sea Studies, 4(2012), pp.471-479; N. TOCCI, Let's talk Turkey! US influence on EU-Turkey relations, in: Cambridge Review of International Affairs, 3(2012), pp.399-416; A. AGNANTOPOULOS, The Europeanization of national foreign policy: explaining Greek support for Turkey's EU accessio, in: Southeast European and Black Sea Studies, 1(2013), pp.67-87; A. GÖL, Turkey's European Future: Behind the Scenes of America's Influence on EU-Turkey Relations, in: Mediterranean Politics, 1(2013), pp.148-150.

64. The UK FCO had "scant regard" for Austria which had a "nasty party" in power which was a "throw back to the siege of Vienna etc.". The deal finally materialised because Verheugen was an old friend of Wolfgang Schüssel, which had helped quite much. Interviews 4 and 17. See also C. SCHNEIDER, Conflict, negotiation and European Union enlargement, Cambridge University Press, Cambridge, 2009.

65. Ankara accepts deal after war of nerves, in: Financial Times, 18.12.2004. 


\section{The Cyprus "issue" and "mon cher Thassos..."}

In October 2004 the Cypriot President, Thassos Papadopoulos, was already unpopular in Brussels because of the Annan Plan referendum result. It was a widely held view in the European Commission that Papadopoulos had "cheated" over his stance on the Annan Plan referendum. ${ }^{66}$ However, in spite of his low approval rating in Brussels Papadopoulos continued to oppose the Turkish case for accession. His tactic was to repeatedly call on the Turkish government to recognise the Republic of Cyprus before accession negotiations could be opened, the so called "Cyprus protocol".

“As a point of principle, Cyprus is not opposed to Turkey's EU accession as long as Turkey behaves towards Cyprus with the same responsibilities and obligations as it does to other EU member states". ${ }^{67}$

Prima facie this was a reasonable request but it was also made in the knowledge that the Turkish government would never agree and therefore created problems for the EU institutions and the big three member states who were acting as advocates for Ankara.

Whilst the government in Nicosia may have lacked credibility within the EU, as a result of the Annan Plan referendum result in April 2004, it nevertheless retained a veto and "could not simply be ignored". ${ }^{68}$ It was, after all, not actually opposing the opening of Turkish accession negotiations but merely asking Ankara to recognise it. However, the political sensitivity of the outcome of the Annan Plan referendum meant Erdogan could not compromise. In advance of the European Council he insisted that the Cyprus issue was a UN issue and "should not be put on the table" at Brussels. ${ }^{69}$

It is ironic therefore that whilst residual normative and cultural opposition to the Turkish case was losing strength within the European Council it was the "Cyprus issue" which came back to haunt the prospects for Turkish accession negotiations to be opened. The Dutch Prime Minister, Jan Peter Balkenende, believed he had resolved the issue with the Turkish Prime Minister, Recep Tayyip Erdogan, in discussions on the evening of Thursday $16^{\text {th }}$ December 2004. However, Balkenende had misread the Turkish sensitivity on Cyprus and the nuances of eastern Mediterranean politics. Turkey knew it had to concede the point but was not able to do so openly. As an unnamed EU ambassador proclaimed at the time, it may have been simply the Dutch national trait of plain speaking. "The Dutch only do black-and-white - they don't do grey". ${ }^{70}$

This misunderstanding resulted in Erdogan's abrupt departure from Brussels on Friday 17th December and he "almost blew it with mercurial behaviour and demands

66. Interview 4.

67. Agence France Press, Cyprus will not veto Turkey if it shows respect for Greek Cypriot government, 14.10.2004.

68. N.P. LUDLOW, A view from Brussels: Dealing with Turkey. The European Council of 16-17th December 2004, Briefing Note 3:7, Eurocomment, Brussels, 2005, p.14.

69. Turkey outlines its terms, in: Financial Times, 08.12.2004.

70. Interview 28; Ankara accepts deal after war of nerves, in: Financial Times 18.12.2004. 
and language". Tony Blair and Gerhard Schroeder were despatched to resolve the situation (Silvio Berlusconi was also present having invited himself along) and "thanks to [Blair's] intervention Erdogan did not leave the Justus Lipsius building [read: the offices of the European Council in Brussels]" and eventually agreed to sign the accession agreement if it was made clear that member states did not consider signing the Protocol to the Ankara Agreement to be the same as formal recognition of the Republic of Cyprus. "Tony Blair more or less persuaded Erdogan personally to (sign the accession agreement)". ${ }^{71}$

Blair had anticipated the difficulty of the Brussels negotiations and had asked Sir Peter Westmacott to attend because of his trusted relationship with the AKP leadership. Westmacott was with Blair as he "patrolled the corridors [...] to find Erdogan" and with his help Blair "more or less persuaded Erdogan personally to sign the documents". Jacques Chirac was called upon to rein in the Cypriot zeal on the Friday morning. Chirac had already taken a political gamble by backing the Turkish case and took a "personal hit" as a result..$^{72}$ However, when Thassos Papadopoulos seemed inclined to push his case for the Cyprus Protocol Chirac said to him: "Mon cher Thassos - we don't do that sort of thing around here"..$^{73}$

\section{The role of the "well-placed Brits"}

The research question addressed here asked why the EU member states agreed to open accession negotiations with Turkey in the face of residual normative and cultural opposition. The answer is that these two categories of opposition to the Turkish case were both counteracted and negated to a large extent by the actions of Turkey's advocates within the EU who were acting for geostrategic reasons.

The normatively opposed states were reassured somewhat by the constitutional reform progress made by Turkey between 2002 and 2004 and the promise this held for more to come. This inclined them to be pragmatic about the "sufficiently fulfilled" wording of the Commission's 2004 Progress Report. It was seen as prudent for the EU to encourage further reform and Europeanization within Turkey. To deny accession negotiations in 2004 may have jeopardised this medium to long term aim. At the same time the constitutional reform progress in Turkey also undermined the case of the more "culturally" opposed states which had previously hidden behind the normative arguments in their opposition to Turkey.

However this neutralisation of opposition was only possible because significant reform progress had actually been made. It remained inconceivable that Turkey could progress to accession purely on the grounds of its geostrategic value. Therefore, in order to be able to make the geostrategic case for Turkey within the EU, it was nec-

71. Interviews 13 and 16; N.P. LUDLOW, op.cit., p.34.

72. Interviews 13,16 and 19.

73. N.P. LUDLOW, op.cit., p.33. 
essary to have a track record of constitutional reform. When examining how this happened the role of the UK FCO also comes to the fore.

The UK had been a long standing geostrategic advocate of Turkey and saw an opportunity after the Copenhagen European Council in December 2002 to further the Turkish case. By this time, the UK FCO had already established the AKP's credibility in terms of willingness and ability to pursue further reforms and between 2002 and 2004 the UK Ambassador in Ankara Sir Peter Westmacott fulfilled the role of unofficial advisor on Europe to the upper echelons of the AKP advising them on how to maximize the chances of a favourable progress report.

The European Commission was also acting from a very similar motivation. Günter Verheugen had been a member of Gerhardt Schroeder's Sozialdemokratische Partei Deutschlands (SPD) government which had been convinced of the geostrategic case for Turkey in the run up to the Helsinki European Council 1999. Furthermore the Commission had several "well placed" Brits working on the Turkish case in the European Commission who were also in tune with FCO policy.

The nature of the rhetorical entrapment is two-fold. Schimmelfennig's 2009 rhetorical entrapment theory is a fundamentally passive process. In repeatedly stressing the significance of the Copenhagen criteria to Turkey over time the EU unintentionally rhetorically entrapped itself when those criteria were at least partly met:

"Its fundamental community norms oblige the EU to consider all applications from European countries according to the same standards of liberal democracy. Turkey's application could thus not be dismissed by reference to socioeconomic or cultural incompatibility. To the extent that Turkey complied with liberal-democratic norms, member states opposed to Turkish membership for economic or cultural reasons could not legitimately block the path to accession but were rhetorically entrapped". ${ }^{74}$

However it is argued here that rhetorical entrapment can also be active or deliberate. In this case rhetorical entrapment was engineered between 2002 and 2004 by actors within the EU who supported Turkey's case for geostrategic reasons. This was made possible by the wording of the Copenhagen 2002 European Council presidency conclusions which threw forward a final decision on the Turkish case by two years and made it dependent on the Commission's progress report. The motivation of the UK FCO, and the European Commission DG Enlargement, was geostrategic. They considered Turkish progress within the EU to be of geostrategic benefit to the EU (and NATO in the case of the FCO) because it would encourage democratic ideals in Turkey and move the eastern Mediterranean away from the political instability of the Cold War period.

The UK FCO and the European Commission were working in parallel but not together in this process. Verheugen had reached his own conclusions in favour of the geostrategic merits of the Turkish case and the Commission was definitely not taking instructions from the UK. However, whilst not working formally in tandem, there was an informal, serendipitous, meeting of minds between the FCO and the Com-

74. F.SCHIMMELFENNIG, Entrapped again ..., op.cit., p.415. 
mission helped by the presence of the "well-placed Brits" who understood the long standing geostrategic position of the FCO and agreed with it.

\section{Conclusion}

This paper has argued that the apparently "controversial" decision to open accession negotiations with Turkey in 2004 can be explained by the rhetorical entrapment of the member states by their previous insistence on the importance of the Copenhagen criteria. Moreover there was an element of deliberate action on the part of Turkey's advocates within the EU, namely the UK, the European Commission DG Enlargement and some "well placed Brits" within the Commission who were all acting out of geostrategic motivation.

The result of the diplomatic assistance given to Turkey between 2002 and 2004 by Sir Peter Westmacott and some Commission officials was that those member states with normative reasons to oppose Turkey were appeased and encouraged to be pragmatic in the hope of further progress. The small minority of member states who had cultural objections found their usual normative reasons were weakened as a result of the progress made and were disinclined to voice the more "cultural" logic in open EU fora.

Additionally, the accession process' poor track record since 2005 can be explained by this artificial expedition of the Turkish case up to 2004/5. The UK strategy was successful in that negotiations were opened but its success had a limited lifespan as it did not change the opinions of Turkey's opponents within the EU but merely obliged them temporarily to act according to its liberal democratic norms and values. Turkey went forward to the opening of negotiations within a hostile environment. Indeed Austria and Cyprus tried very hard to scupper the opening of negotiations in October 2005 and were only stopped by the determined and effective diplomacy of the UK which, by chance, held the presidency at the time. ${ }^{75}$

Just as the offer of candidacy in 1999 was only meaningful if constitutional reform progress was made, the same applied to the opening of accession negotiations. Turkey could only move further along the accession path if it continued to make progress towards meeting the Copenhagen criteria. In the absence of such progress - for rea-

75. Interview 40. See also N.MARTIN, Security and the EU-Turkey Accession Process: Norms, Reforms and the Cyprus issue, Palgrave, London, 2015. 
sons outside the remit of this article ${ }^{76}$ - it was increasingly difficult thereafter for Turkey's advocates within the EU to counter its opponents thus creating the vicious cycle of decline in the accession process which has led to the current situation. The role of the UK from 2002 to 2004 goes some way to explain the marked contrast of the apparent enthusiasm for Turkish accession by the EU in 2004 (and the appetite for reform of the AKP during that time) and since. It also raises the question of whether at least some of the credit for the AKP's unprecedented, and unrepeated, zest for reform in the early years actually belongs to the UK FCO. This may be a useful future research agenda for those trying to explain the current parlous situation.

\section{Appendix - List of interviews ${ }^{77}$}

\begin{tabular}{l|l|l}
\multirow{2}{*}{ Interview } & Interviewed Person & Date \\
\cline { 2 - 3 } 2 & Senior European Commission official B & April 2009 \\
3 & Senior European Commission official A 2a, 2b & April 2009/March 2010 \\
4 & Senior European Commission official C & March 2010 \\
7 & Senior European Commission official D & August 2010 \\
9 & Senior official in European Council DG Enlargement B & March 2010 \\
11 & Senior ESDP advisor A & March 2010 \\
13 & Senior UK politician A & March 2010 \\
15 & Senior UK politician C & September 2010 \\
16 & Senior UK Diplomat A & March 2010 \\
17 & Senior UK Diplomat B & March 2010 \\
18 & Senior UK Diplomat C & April 2010 \\
19 & Senior UK Diplomat D & April 2010 \\
20 & Senior UK Diplomat E & May 2010 \\
21 & Senior UK Diplomat F & June 2010 \\
23 & Senior WEU official & February 2010 \\
25 & Senior UK Diplomat J & October 2010 \\
26 & Senior Turkish politician A & TUSIAD official \\
28 & Senior Turkish diplomat A & March 2010 \\
38 & Dutch Diplomat A & March 2010 \\
40 & Swedish Diplomat A & June 2012 \\
& Senior UK Diplomat K & March 2010 \\
& & March 2010
\end{tabular}

76. See G. AVCI, The Justice and Development Party and the EU: Political Pragmatism in a Changing Environment, in: South European Society and Politics, 3(2011), pp.409-421; E. KALAYCIOĞLU, The Turkish-EU Odyssey and Political Regime Change in Turkey, in: South European Society and Politics, 2(2011), pp.265-278; E. ICENER, Z. ÇAĞLIYAN-İÇENER, The Justice and Development Party's identity and its role in the EU's decision to open accession negotiations with Turkey, in: Journal of South East European and Black Sea Studies, 1(2011), pp.19-34 and M. MÜFTÜLERBAÇ, E.F. KEYMAN, The Era of Dominant-Party Politics, in: Journal of Democracy, 1(2012), pp. 85-99.

77. The author would like to thank all the interviewees in Ankara, Brussels and various member state governments who, although busy, gave freely of their time. 